\title{
RIPLEY PIERCE BULLEN, 1902-1976
}

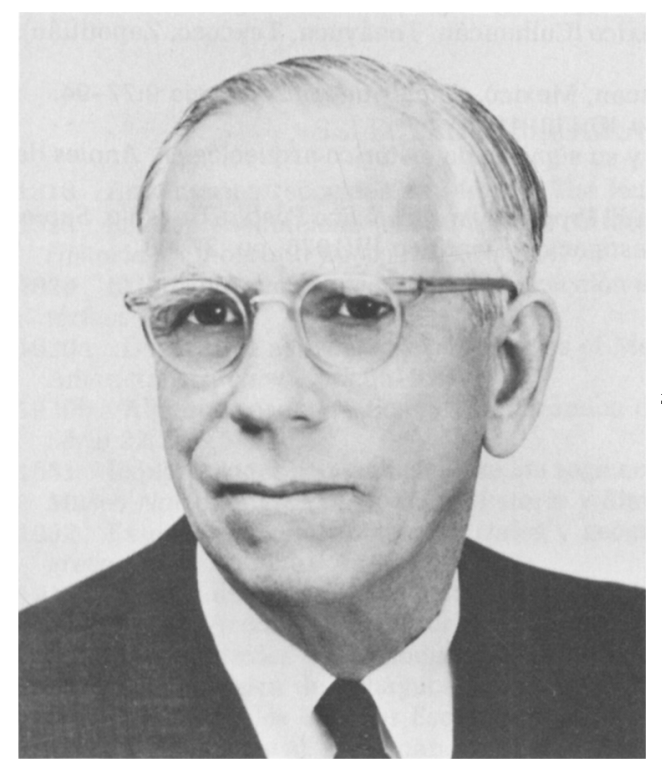

Ripley P. Bullen, Curator Emeritus at the Florida State Museum, University of Florida, died in Gainesville December 25, 1976, at the age of 74 . Although often associated with Florida and Southeastern archaeology, his professional interests and research encompassed, additionally, New England, the American Southwest, the Lesser Antilles, Greater Antilles, and Central America. His bibliography reflects a prodigious investigator whose tireless efforts have substantially advanced the understanding of New World prehistory.

Ripley was born in Winthrop, Massachusetts, on September 21, 1902, the son of Dana Ripley Bullen and Bessie Louise Pierce. With interests in both archaeology and engineering, he graduated from Schenectady High School, New York, in 1921. Choosing engineering as his major field of study, he entered Cornell University and received an M.E. degree in mechanical engineering in 1925. He began work with the General Electric Company that same year, and for the next 15 years he was involved first in engineering research and then sales in New York and Massachusetts. In Massachusetts he met his future wife, Adelaide Kendall; they were married in 1929. During this time period his earlier archaeological interest persisted and actively manifested itself in the excavation (1939-1940) of a steatite quarry near Worcester, Massachusetts, in his activities as one of the organizers (1939) of the Massachusetts Archaeological Society, and in his presentations of research results at local and professional meetings, including the Society for American Archaeology.

By 1940 his expanding interest in archaeology was such that he left General Electric for the staff of the Robert S. Peabody Foundation for Archaeology at Phillips Academy, Andover, Massachusetts. He also began graduate work in anthropology at Harvard University and became a Teaching Fellow (1943-1945). During 1941 he attended the University of New Mexico archaeological field school and worked in and around Chaco Canyon. While at the R.S. Peabody Foundation, he undertook, with characteristic energy, numerous excavations and surveys and established the basic cultural chronology for eastern Massachusetts. During his 8 years in Andover, Ripley published a prolific 38 articles covering his Precolumbian and historical excavations, artifact classification, and field methods. His 1944 integration of thorough archival and excavation techniques in the investigation of the eighteenth-century Black Lucy's Garden in Andover constitutes an early model of modern historical archaeology. He also taught classes and made frequent presentations to the Massachusetts Archaeological Society and at professional meetings.

In 1948 Ripley accepted the position of Assistant Archaeologist with the Florida Board of Parks and Historic Memorials in Gainesville, Florida. He began a broad program of research and, in the year of his arrival, helped found the Florida Anthropological Society and its journal, The Florida Anthropologist. During the next 4 years he published 27 papers reporting current investigations throughout the state.

In 1952 the Florida Park Service discontinued its archaeological program, transferring its collections and data to the Florida State Museum, which was reorganized and a new Department of Social Sciences established. Ripley was appointed the first curator of Social Sciences and became department chairman, a post to which he applied his energies for 17 years.

Perhaps diagnostic of his view of professionalism was his ready accessibility and rapport with 
a wide range of people, professional colleagues and amateurs alike. One never wrote to Ripley without receiving a reply, and most often a very thorough one. He was exceedingly generous with his knowledge and time and came to be highly regarded throughout Florida and the diverse regions where he worked. Under his tutelage, the Florida Anthropological Society grew to be one of the most active of the regional societies. Editing its journal (a job he began in 1970) consumed much of his time, but he kept standards among the highest for such publications. Unquestionably, his impact upon the society and interested laymen led to a more positive activism throughout the state that resulted in the preservation of many important sites and the recording of otherwise inaccessible data.

In 1956 he initiated and began editing the monograph series, Contributions of the Florida State Museum, Social Sciences. His numerous Florida excavations brought large scientific collections to the Museum, and his influence with interested Floridians led to sizeable artifact donations. The growth was rapid, and soon the new Social Sciences Department was cramped for space; by 1969, the year he retired as chairman, 70,000 North American items had been added to the collections.

Ripley's research in Florida resulted in the recording of hundreds of archaeological sites. It also brought about a refinement of cultural chronology, especially the Florida Orange period (2000-1200 B.C.), whose fiber-tempered pottery particularly interested him. He also delineated the Transitional period (1200-500 B.C.) in Florida. His effective use of radiocarbon dating, which he was the first to utilize in Florida, greatly helped in clarifying and extending the culture sequence. Extensive analysis of lithic artifacts led to his definitive $A$ Guide to the Identification of Florida Projectile Points, now in its second editon.

In the field, Ripley had a talent for locating and excavating sites with long sequential occupations. One of his major regions of concentration was the central Gulf coast of Florida. Numerous excavations focused on the Safety Harbor culture, the archaeological manifestation of the prehistoric and historic Tocobagas. Ripley also excavated and reported on a number of earlier central peninsular Gulf coast sites, some dating from the Archaic period. At the Palmer site he found a 2000 B.C.-1100 A.D. culture sequence and an unusual alligator burial, which he interpreted as a totemic interment. Another area of endeavor was east Florida, including the Atlantic coast north of Cape Canaveral and the St. Johns River Valley. Here he refined and radiocarbondated the culture sequence from 3500 B.C. to the historic period. He produced important data on the seasonality of the historic Timucuan peoples and their evolution from the earlier Archaic hunters and gatherers.

At Crystal River, on the northern peninsular Gulf coast of Florida, Ripley encountered in 1951, 1960, and 1964-1965, non-Southeastern features that suggested outside contact. Here he excavated plaza-mound arrangements reminiscent of lowland Mesoamerica and identified 3 stelae. Radiocarbon dates indicated a 30 B.C. -1200 A.D. occupation and an approximate 440 A.D. date for the stelae. Realizing the necessity for preserving the site, he effectively suggested to state legislators and the Florida Park Board the creation of a museum and park. He reconstructed the mounds to conform as nearly as possible to their original contours, which had been disturbed by early twentieth century investigations and earth removal. In 1962 a large park was established and later a museum. For the latter he spent considerable time organizing the archaeological materials for exhibits and preparing data for a scale model of the site.

Although Ripley had examined trade contacts with the Mississippian area and general Southeastern relationships in the course of his research, the nature of possible prehistoric contact with the islands of the Caribbean remained unknown. After excavations at Castle Windy and Green Mound in East Florida in 1956-1957, he became increasingly concerned with the Caribbean. He began preliminary arrangements to examine sites in Cuba, but political events obligated him to work elsewhere. He began actual fieldwork during 1959 in the Virgin Islands and the following year excavated an important site at Krum Bay, St. Thomas, and surveyed St. John. Here his work was initially in collaboration with Frederick W. Sleight of the Central Florida Museum and took place under the additional sponsorship of the Florida State Museum, William L. Bryant Foundation, and the National Park Service. 
His work in the Lesser Antilles documented an involved cultural chronology beginning with the first ceramics about 200 B.C. He saw influences in this sequence, first from northeastern Venezuela, then from the Greater Antilles, and finally (about 1200 A.D.) from the expanding Island Caribs (Suazey), who probably originated in the Guianas. One of his intriguing conclusions concerning the Greater Antilles was the probability of an early peopling from Honduras and Nicaragua via Jamaica. He also concluded that there was no preceramic or early ceramic period migration from Florida to the Antilles.

During 1963 he examined preceramic sites in Honduras and documented early stone tools at elevated locations in the interior. Without neglecting his Florida research, extensive museum exhibits, and editing duties, he continued to expand his Caribbean investigations. He undertook major island-wide projects in Grenada, Barbados, St. Vincent, the Grenadines, and St. Lucia. By 1967, he also examined or excavated sites in St. Croix, Martinique, Marie Galante, Guadeloupe, St. Martin, Trinidad, Tobago, Curacao, Aruba, Guyana, Surinam, Puerto Rico, Dominican Republic, Jamaica, and the Bahamas.

Ripley was a regular participant, with his wife Adelaide, a physical and cultural anthropologist, in numerous international conferences. He gave papers at the International Congress of Americanists (San José, Vienna, Mexico City, Barcelona, Lima, and Rome), at the World Congress of Anthropological and Ethnological Sciences (Paris, Moscow, Tokyo, and Kyoto), and at the International Congress for the Study of Pre-Columbian Cultures of the Lesser Antilles (Martinique, Barbados, Grenada, St. Lucia, Antigua, and Guadeloupe). He reorganized the Lesser Antilles conferences and edited 5 of their Proceedings. He also was invited to participate in special conferences on petroglyphs (sponsored by the Carnegie Museum, Pittsburgh, in 1975) and on Mesoamerica, (sponsored by Christ's College, Cambridge University, in 1972).

His consistent fieldwork, editorial endeavors, and willingness to share information were recognized by his colleagues in the Caribbean, and he was elected Chairman for Life of the International Congress of the Lesser Antilles. His concern for cultural origins in the Caribbean led him to study artifacts in diverse locations, including Jomon pottery in Japan in 1968, early pottery in Colombia in 1969, and Antillian material at the Danish National Museum during 1964.

In 1969 Ripley retired as the Chairman of the Department of Social Sciences, Florida State Museum, though he continued his curatorial duties as well as his preparation of The Florida Anthropologist, the Proceedings, and "Current Research" of the Caribbean for American Antiquity. He also kept up his writing and continued his fieldwork, both in Florida and the Caribbean, working at several central Florida sites and on St. Vincent, the Grenadines, Martinique, and Puerto Rico. In 1973 he retired from the Department but, as Curator Emeritus, continued to use his office and facilities in the Museum where he could be found working daily.

On March 20, 1976, the University of Florida awarded Ripley an honorary Doctor of Science degree in recognition of his distinguished career and exceptional service to the University. He accepted the degree in his unpretentious way and continued his strenuous program of manuscript preparation. He edited and prepared numerous manuscripts during 1976, working regularly to within a few days of his death. He conscientiously made provisions for transferring his editorships of The Florida Anthropologist, and Proceedings of the International Congress of the Lesser Antilles and contributing editorship in archaeology for the Handbook of Latin American Studies. He also arranged for final completion of any manuscripts he might not finish.

Ripley's amiable personality and modesty, together with his great competence, earned him hundreds of friends throughout the United States and the Caribbean. He was always sought out at meetings and could be found in the midst of discussion with old colleagues and neophytes alike. Undaunted by controversy, he would always speak out and added new dimensions to many interpretations. Entertainment at the Bullens' well-appointed home in Gainesville was invariably extremely hospitable and was the high point of visits by many colleagues over the years. One never failed to sense his enthusiasm and availability in both formal and informal situations. To me, and to many, it was an enlightening privilege to have known him.

Ripley is survived by his wife, Adelaide K. Bullen (Research Associate in Anthropology, Florida State Museum); 2 sons, Dana Ripley II and Pierce Kendall; and 4 grandchildren. 
(This obituary and the bibliography compiled by Adelaide $\mathrm{K}$. Bullen will also be included in the proceedings of the Seventh International Congress for the Study of Pre-Columbian Cultures of the Lesser Antilles, held in honor of Ripley in Caracas, Venezuela, 1977.)

\title{
S. JEFFREY K. WILKERSON
}

\author{
BIBLIOGRAPHY OF RIPLEY P. BULLEN * \\ [Compiled by Adelaide K. Bullen)
}

1939 Instructions for the site survey. Bulletin of the Massachusetts Archaeological Society 1[1):8-10.

1940a Cultural relationships and terminology in New England. Bulletin of the Massachusetts Archaeological Society 1(3):27-29.

1940b. The Dolly Bond steatite quarry. Bulletin of the Massachusetts Archaeological Society 2(1):14-22.

1940c Further notes on the Dolly Bond steatite quarry. Society for American Archaeology, Notebook. November, pp. 158-160.

1941a Preliminary report Bc 54, Chaco Canyon, New Mexico. On file, Division of Chaco Research (Chaco Center). University of New Mexico, Albuquerque. (49 pp. plus site map)

1941b Report on the site survey to February, 1941. Bulletin of the Massachusetts Archaeological Society 2 [3]:2-9.

1942a An anthropological world. American Anthropologist 44:525-526.

1942b Forts, boundaries, or ha-has? Bulletin of the Massachusetts Archaeological Society 4(1):1-11.

1942c (with A.K. Bullen). A Pueblo cave site at Tres Piedras, New Mexico. American Antiquity 8:57-64.

1943a Proposed drill classification. Bulletin of the Massachusetts Archaeological Society 4:48.

1943b A proposed Massachusetts projectile point classification. Bulletin of the Massachusetts Archaeological Society 4:45-47.

1943c (with D.H. Howell). Spectrographic analysis of some New England steatite. Bulletin of the Massachusetts Archaeological Society 4:62-64.

1944a Corn goddesses or phalli? American Antiquity 9:448-449.

$1944 \mathrm{~b}$ The geographer as an aid in archaeological problems. Bulletin of the Massachusetts Archaeological Society 5:33-34.

1944C (with A.M. Hofmann). The Hofmann site. American Antiquity 10:186-197.

1944d A note on "The pre-Iroquoian occupations of New York state," By William A. Ritchie, Bulletin of the Massachusetts Archaeological Society 5:48.

$1944 \mathrm{e}$ Review of The pre-Iroquoian occupations of New York state, by William A. Ritchie. Bulletin of the Massachusetts Archaeological Society 5:60-64.

1944f (with A.M. Hofmann). The Stickney site, Ballardvale, Massachusetts. Bulletin of the Massachusetts Archaeological Society 5:20-25.

1945a (with A.K. Bullen). Black Lucy's garden. Bulletin of the Massachusetts Archaeological Society 6:17-28.

1945b (with M. Robbins). An Indian burial at South Dartmouth, Massachusetts. Bulletin of the Massachusetts Archaeological Society 6:44-45.

1946a (with H. Torrey). A burial pit at Taylor Hill, Wellfleet, Massachusetts. Bulletin of the Massachusetts Archaeological Society 7:65-67.

1946b The Dwight Blaney collection. Bulletin of the Massachusetts Archaeological Society 7:77.

1946c The Foster's Cove site. Bulletin of the Massachusetts Archaeological Society 7:24-36.

1946d An Indian site in Andover. Massachusetts. Bulletin of the Massachusetts Archaeological Society $7: 37-42$.

1946e Review of Archaeology of New Jersey (Vol. I), by Dorothy Cross. Bulletin of the Massachusetts Archaeological Society 8:8-10.

$1946 \mathrm{f}$ Suggestions of stratigraphy in eastern Massachusetts. Bulletin of the Massachusetts Archaeological Society 7:54-59.

$1946 \mathrm{~g}$ (with A.K. Bullen). Two burials at Tiverton, Rhode Island. Bulletin of the Massachusetts Archaeological Society 8:5-6.

1947a The Ernest S. Clarke collection. Bulletin of the Massachusetts Archaeological Society 8:47-48.

1947b (with J.F. Burtt). The Neck Creek shell heap, Ipswich, Massachusetts. Bulletin of the Massachusetts Archaeological Society 9:4-8.

1947c Notes on pre-historic relics from three Beverly graves. Bulletin of the Massachusetts Archaeological Society 8:22-24.

1947d (with E. Brooks). The Squam Pond Indian site, Nantucket, Massachusetts. Bulletin of the Massachusetts Archaeological Society 8:56-59.

*This bibliography is as complete as possible at this time. Please send corrections or additions for future inclusion to Adelaide K. Bullen, Florida State Museum, University of Florida, Gainesville, FL 32611. 
1948a Culture dynamics in eastern Massachusetts. American Antiquity 14:36-48.

$1948 \mathrm{~b}$ Review of The Archaic horizon in western Tennessee, by Thomas M.N. Lewis and Madeline Kneberg. Florida Anthropologist 1:78.

1948c Review of The Flint River site, $\mathrm{Ma}^{\circ} 48$, by Wm. S. Webb and David L. DeJarnette. Florida Anthropologist 1:75-77.

1948d A rock shelter near Worcester. Bulletin of the Massachusetts Archaeological Society 10:16.

1948e (with E. Brooks). Shell heaps on Sandy Neck, Barnstable, Massachusetts. Bulletin of the Massachusetts Archaeological Society 10:7-13.

1948f Some types of Massachusetts pottery. Eastern States Archeological Federation, Bulletin 7:15-16.

$1948 \mathrm{~g}$ (with E. Brooks). Three burials at the Hughes site, Nantucket, Massachusetts. Bulletin of the Massachusetts Archaeological Society 10:14-15.

1949a Excavations in northeastern Massachusetts. Papers of the Robert S. Peabody Foundation for Archaeology 1(3). (152 pp. plus 20 plates)

1949b (with E. Brooks). The Herrecater Swamp site, Nantucket Island, Massachusetts. Bulletin of the Massachusetts Archaeology Society 10:81-89.

1949c Indian sites at Florida Caverns State Park. Florida Anthropologist 2:1-9.

1950a An archeological survey of the Chattahoochee River Valley in Florida. Journal of the Washington Academy of Sciences 40(4):101-125.

1950b Chronology and Virginian prehistory. Quarterly Bulletin, Archeological Society of Virginia 4(3):2-6.

1950c (with A.K. Bullen). The Johns Island site, Hernando County, Florida. American Antiquity 16:23 45.

1950d The Johnson's Spring site. Bulletin of the Massachusetts Archaeological Society 11:37-45.

1950e Review of Excavations in southeast Florida, by Gordon R. Willey. Florida Historical Quarterly 29:51-53.

1950 f (with J.W. Griffin). The Safety Harbor site, Pinellas County, Florida. Florida Anthropological Society, Publications 2. (42 pp.)

$1950 \mathrm{~g}$ Tests at the Whittaker site, Sarasota, Florida. Florida Anthropologist 3:21-30.

1950h The Woodward site. Florida Anthropologist [1949] 2:49-64.

1951a Archeology of the Tampa Bay area. Florida Historical Quarterly 30:133-135.

1951b Certain small triangular arrow points. Bulletin of the Massachusetts Archaeological Society 12:64-

66.

1951c The enigmatic Crystal River site. American Antiquity 17:142-143.

1951d Fort Tonyn and the campaign of 1778. Florida Historical Quarterly 29:253-260.

1951e The Gard site, Homosassa Springs, Florida. Florida Anthropologist 4:27-31.

1951 History along route A1A. Florida Highways 19(9):22-23.

$1951 \mathrm{~g}$ Perico Island: 1950. Florida Anthropologist [1950] 3:40-44.

$1951 \mathrm{~h}$ Review of Excavations at Kolomoki, season I-1948, by William H. Sears. Florida Anthropologist 4:32-

1951i Some notes on the Winslow site. Bulletin of the Massachusetts Archaeological Society 13(1):10-11.

1951j The Terra Ceia site, Manatee County, Florida. Florida Anthropological Society. Publications 3.

$1951 \mathrm{k}$ Worcester's first industry. Nature Outlook 9:10-11, 26. Worcester Natural History Society, Worcester, Massachusetts.

1952a (with J.W. Griffin). An archaeological survey of Amelia Island, Florida. Florida Anthropologist 5:3764.

1952b Culture growth and change in eastern Massachusetts. Bulletin of the Massachusetts Archaeological Society $13(2): 8-10$.

1952c De Soto's Ucita and the Terra Ceia site. Florida Historical Quarterly 30:317-323.

1952d Eleven archaeological sites in Hillsborough County, Florida. Florida Geological Survey, Report of Investigations 8 .

1952e (with G.R. Reeder, B. Bell, and B. Whisenant). The Harbor Key site, Manatee County, Florida. Florida Anthropologist 5:21-23.

$1952 \mathrm{f}$ Review of Excavations at Kolomoki, season II-1950 by William H. Sears. Florida Anthropologist $4: 76-77$.

$1952 \mathrm{~g}$ S.T. Walker, an early Florida archaeologist. Florida Anthropologist 4:46-49.

1953a (with A.K. Bullen). The Battery Point site, Bayport. Hernando County, Florida. Florida Anthropologist 6:85-92.

1953b Excavations at Manatee Springs, Florida. Florida Anthropologist 6:53-68.

1953c The famous Crystal River site. Florida Anthropologist 6:9-37.

1953d Notes on the Seminole archaeology of west Florida. Southeastern Archaeological Conference [1952], Newsletter 3(3):18-19.

1953e A partial reply to Fowler's "Comments on 'Culture growth and change in eastern Massachusetts.' " Bulletin of the Massachusetts Archaeological Society 14:74-76.

1954 a Culture changes during the fiber-tempered period in Florida. Southeastern Archaeological Conference [1953], Newsletter 4:45-48 (published as Southern Indian Studies 5 [i.e., 6]).

1954b The Davis mound, Hardee County, Florida. Florida Anthropologist 7:97-102. 
1954c (with A.K. Bullen). Further notes on the Battery Point site, Bayport, Hernando County, Florida. Florida Anthropologist 7:103-108.

1954d (with D.D. Laxson). Some incised pottery from Cuba and Florida. Florida Anthropologist 7:23-25.

1954e A unique St. Johns punctated vessel. Florida Anthropologist 7:72-73.

1955a Archeology of the Tampa Bay area. Florida Historical Quarterly 34:51-63.

1955b Carved owl totem, DeLand, Florida. Florida Anthropologist 8:61-73.

1955c (with W.T. Neill). Muskrat remains from a prehistoric Indian site in Jackson County, Florida. Journal of Mammology 36:138.

1955d Stratigraphic tests at Bluffton, Volusia County, Florida. Florida Anthropologist 8:1-16.

1956a (with A.K. Bullen). Excavations on Cape Haze Peninsula, Florida. Contributions of the Florida State Museum, Social Sciences 1. (56 pp. plus 6 plates)

1956b Some Florida radiocarbon dates and their significance. Florida Anthropologist 9:31-46.

1957 The Barnhill mound, Palm Beach County, Florida. Florida Anthropologist 10:23-36.

1958a The Bolen Bluff site on Paynes Prairie, Florida. Contributions of the Florida State Museum, Social Sciences 4. (38 pp. plus 10 plates)

1958b (with W.M. Sackett). Dates of Busycon gouges at the Bluffton site, Florida. Florida Anthropologist 11:111-113.

1958c More Florida radiocarbon dates and their significance. Florida Anthropologist 11:97-110.

1958 dix sites near the Chattahoochee River in the Jim Woodruff Reservoir area, Florida. River Basin Surveys Papers, No. 14. Smithsonian Institution Bureau of American Ethnology, Bulletin 169:315-357. (17 plates)

1958 e Some comments on the mooring hole problem. Bulletin of the Massachusetts Archaeological Society 19:50

1958f A unique vessel from Murphy Island, Putnam County, Florida. Florida Anthropologist 11:125-127.

1959a (with F.W. Sleight). Archaeological investigations of the Castle Windy midden, Florida. The William L. Bryant Foundation, American Studies, Report 1.

1959b (with E.M. Dolan). The Johnson Lake site, Marion County, Florida. Florida Anthropologist 12:77-94.

1959c Radiocarbon dating of the earliest pottery in Florida. Actas del XXXIII Congreso Internacional de Americanistas, San José, Costa Rica, 1958, 2:101-106.

1959d Similarities in pottery decoration from Florida, Cuba, and the Bahamas. Actas del XXXIII Congreso Internacional de Americanistas, San José, Costa Rica, 1958, 2:107-110.

1959e The transitional period of Florida. Southeastern Archaeological Conference, Newsletter 6:43-53, 5962.

1959 What was it? Florida Anthropologist 12:75-76.

1960a (with F.W. Sleight). Archaeological investigations of Green Mound, Florida. The William L. Bryant Foundation, American Studies, Report 2.

1960b (with E.M. Dolan). Shell Mound, Levy County, Florida. Florida Anthropologist 13:17-24.

1961a Radiocarbon dates for Southeastern fiber-tempered pottery. American Antiquity 27:104-106.

1961 b (with A.K. Bullen). The Summer Haven site, St. Johns County, Florida. Florida Anthropologist 14:1-15.

1961c (with A.K. Bullen). Wash Island in Crystal River. Florida Anthropologist14:69-73.

1961-1962 Florida's Indian cultures. Two part series appearing in Florida newspapers, including Dunedin Times, Feb. 15, 1962 (pt. 1), Mar. 29, 1962 (pt. 2); Eustis News, Nov. 9, 1961 (pt. 1); Fernandina News Leader, Nov. 9, 1961 (pt. 1); Haines City Herald, Nov. 2, 1961 (pt. 1); Havana Herald, Dec. 21, 1961 (pt. 1); Indian Town Press, Nov. 9, 1961 (pt. 1). Dec. 28, 1961 (pt. 2); Kissimmee Gazette, Jan. 11, 1962 (pt, 2); Monticello News, Jan. 5, 1962 (pt. 1), Jan. 12, 1962 (pt. 2); Perry News Herald, Nov. 2, 1961 (pt. 1), Dec. 14, 1961 (pt. 2); Playground News, Ft. Walton Beach, Nov. 14, 1961 (pt. 1); Polk County Democrat, Dec. 7, 1961 (pt. 1 ); Sumter County News, Nov. 2,1961 (pt. 1), Dec. 14, 1961 (pt. 2); Suwannee Democrat, Live Oak, Dec. 14, 1961 (pt. 2); Tampa Independent, Nov. 10, 1961 (pt. 1); Washington County News, Nov. 2, 1961 (pt. 1).

1962a Ceramic periods of St. Thomas and St. John islands, Virgin Islands. The William L. Bryant Foundation, American Studies, Report 4. (2nd printing, 1974).

1962b A human head adorno from the Vance site. Florida Anthropologist 15:11-12.

1962c Indian burials at Tick Island. American Philosophical Society, Yearbook 1961, pp. 477-480.

1962d Perforated deer phalanges in the Simpson collection. Florida Anthropologist 15:111-112.

1962e The preceramic Krum Bay site, Virgin Islands, and its relationship to the peopling of the Caribbean. Akten des 34. Internationalen Amerikanistenkongresses, Wien [Vienna], 1960, pp. 398-403.

$1962 \mathrm{f}$ St. Johns Incised, Pasco Incised, etc. Southeastern Archaeological Conference [1959], Newsletter 8:1-2.

1962g Suwannee points in the Simpson collection. Florida Anthropologist 15:83-88.

1963a Artifacts, fossils, and a radiocarbon date from Seminole Field, Florida. Quarterly Journal of the Florida Academy of Sciences 26:293-303.

1963b The earliest pottery in southeastern United States, 2000-1000 B.C., and its case as an independent invention. VI Congrès International des Sciences Anthropologiques et Ethnologiques, Paris, 1960, 2(1):363-367.

1963c (with F.W. Sleight). The Krum Bay site, a preceramic site on St. Thomas, United States Virgin Islands. 
The William L. Bryant Foundation, American Studies, Report 5.

1963 dwith A.K. Bullen). The Lemon Bay School mound. Florida Anthropologist 16:51-56.

1963e (with W.W. Plowden, Jr.). Preceramic Archaic sites in the highlands of Honduras. American Antiquity 28:382-385.

$1963 \mathrm{f}$ Shell pendants in the Simpson collection. Florida Anthropologist 16:63-64.

1963g (with A.K. Bullen). The Wash Island site, Crystal River, Florida. Florida Anthropologist 16:81-92.

1964a Archaeological research at Grenada, West Indies. American Philosophical Society. Yearbook 1963, pp. 511-514.

1964b The archaeology of Grenada, West Indies. Contributions of the Florida State Museum, Social Sciences

11. (67 pp. plus 25 plates) (2nd printing, Kendall Books, Gainesville, 1978)

1964c (with C.A. Benson). Dixie Lime caves numbers 1 and 2, a preliminary report. Florida Anthropologist 17:153-164.

1964d Krum Bay, a preceramic workshop in the Virgin Islands. Premier Congrès International d'Etudes des Civilisations Précolombiennes des Petites Antilles, Martinique, 1961, Part II, pp. 107-120. Société d'Histoire de la Martinique, Fort-de-France.

1964e Krum Bay, un atelier préceramique aux Iles Vierges. Premier Congrès International d'Etudes des Civilisations Précolombiennes des Petites Antilles, Martinique, 1961, Part II, pp. 121-126. Société d'Histoire de la Martinique, Fort-de-France.

$1964 f$ (with W.W. Plowden, Jr.). Preceramic Archaic sites in the central highlands of Honduras. XXXV Congreso Internacional de Americanistas, Méxica, 1962, Actas y Memorias 1:563-564.

1965a Analysis of the Hatt collection from the Virgin Islands and preserved at the Danish National Museum, Copenhagen. American Philosophical Society, Yearbook 1964, pp. 461-462.

1965b Archaeological chronology of Grenada. American Antiquity 31:237-241.

1965c Caribbean symposium: introduction. American Antiquity 31:224-225.

1965d (with L.O. Warren). A Dalton complex from Florida. Florida Anthropologist 18:29-32.

1965e Florida's prehistory. In Florida from Indian trail to space age. by C.W. Tebeau and R.L. Carson, pp. 305-316. Southern Publishing, Delray Beach, Florida.

$1965 f$ (with W.J. Bryant). Three Archaic sites in the Ocala National Forest, Florida. The William $L$. Bryant Foundation, American Studies, Report 6. (30 pp. plus 2 plates)

1966a The archaeology of Grenada, West Indies, and the spread of ceramic people in the Antilles. XXXVI Congreso Internacional de Americanistas, España, 1964, Actas y Memorias 1:435-439.

$1966 \mathrm{~b}$ (with A.K. Bullen). Barbados, a Carib centre. The Bajan and South Caribbean, 20-22.

1966c Barbados and the archaeology of the Caribbean. The Journal of the Barbados Museum and Historical Society 32(1):16-19.

1966d Burtine Island, Citrus County, Florida. Contributions of the Florida State Museum, Social Sciences 14.

1966e The first English settlement on St. Lucia. Caribbean Quarterly 12(2):29-35.

$1966 f$ Florida West Coast from Crystal River south. In "The transition from Archaic to Woodland: a symposium." Southeastern Archaeological Conference [1960], Newsletter 10[1):10-11.

1966g Proposed Caribbean ceramic terminology. Report of the First Bahamas Conference on Archeology, San Salvador, pp. 15-16. New Haven.

1966h Review of Estudio de las hachas Antillanas, by Herrera Fritot. American Antiquity 31:595-596.

1966i Significance of the conference. Report of the First Bahamas Conference on Archeology, San Salvador, p. 3. New Haven.

1966j Stelae at the Crystal River site, Florida. American Antiquity 31:861-865.

1966k (with A.K. Bullen). Three Indian sites on St. Martin. Nieuwe West-Indische Gids, 45:137-144. (3 plates)

1967a (with A.K. Bullen and W.J. Bryant). Archaeological investigations at the Ross Hammock site, Florida. The William L. Bryant Foundation, American Studies, Report 7.

1967b Archaeology: Caribbean area. Handbook of Latin American Studies 29:69-75. University of Florida Press, Gainesville.

1967c (with L.O. Warren and W. Thompson). The Culbreath Bayou site, Hillsborough County, Florida. Florida Anthropologist 20:146-163.

1967d (with C.A. Benson). Cut wolf jaws from Tick Island, Florida. Florida Anthropologist 20:175-177.

1967e Review of Excavaciones en Arroyo del Palo, Mayari, Cuba, by Ernesto E. Tabio and J.M. Guarch. American Anthropologist 69:777-778.

$1967 \mathrm{f}$ Review of Prehistoria de Cuba, by E.E. Tabío and E. Rey. American Antiquity 32:556-557.

$1967 \mathrm{~g}$ (with H.K. Brooks). Two ancient Florida dugout canoes. Quarterly Journal of the Florida Academy of Sciences 30:97-107.

1968a (with A.K. Bullen). Barbados archaeology: 1966. Proceedings of the Second International Congress for the Study of Pre-Columbian Cultures in the Lesser Antilles, Barbados, 1967, pp. 134-144.

1968b A Florida folsom (?) point. Florida Anthropologist 20:2.

1968c A guide to the identification of Florida projectile points. Florida State Museum, Gainesville, Florida. (See $1975 \mathrm{~b}$, revised edition).

1968d The Pearsall collection of aboriginal Indian artifacts. Southeastern Museums Conference, Quarterly Notes, Summer 1968, pp. 14-17. Lowe Art Museum, University of Miami, Coral Gables, Florida. 
1968e Report of the Florida-south Georgia group. Southeastern Archaeological Conference, Bulletin 8:7-10. 1968 (with A.K. Bullen). Salvage archaeology at Caliviny Island, Grenada: a problem in typology. Proceedings of the Second International Congress for the Study of Pre-Columbian Cultures in the Lesser Antilles, Barbados, 1967, pp. 31-43.

$1968 \mathrm{~g}$ Some Arawak ceramic variations between Grenada, Barbados, St. Lucia, and eastern Trinidad. Proceedings of the Second International Congress for the Study of Pre-Columbian Cultures in the Lesser Antilles. Barbados, 1967, pp. 81-86.

1968h Sunday Bluff. Southeastern Archaeological Conference. Newsletter 12(1):5.

1968i Sunday Bluff site. Southeastern Archaeological Conference, Newsletter 12(2):4

1968j (with A.K. Bullen). Two stratigraphic tests at the Grande Anse site, St. Lucia. In The Amerindians in St. Lucia by C. Jesse, pp. 24-41. St. Lucia Archaeological and Historical Society.

1969a Archaeology: Caribbean area. Handbook of Latin American Studies 31:61-67. University of Florida Press, Gainesville.

1969b Beveled stemmed points from Tampa Bay. Florida Anthropologist 21:89-90.

1969c (with A.K. Bullen and C.J. Clausen). The Cato site near Sebastion Inlet, Florida. Florida Anthropologist 21:14-16.

1969d A composite bone fishhook. Florida Anthropologist 21:124.

1969 e Discussion [of lithic papers]. Southeastern Archaeological Conference, Bulletin 9:13-14,20,30,31,32.

1969 f Excavations at Sunday Bluff, Florida. Contributions of the Florida State Museum, Social Sciences 15.

$1969 \mathrm{~g}$ Further comments on Emery and Edwards" "Archaeological potential of the Atlantic shelf." American Antiquity 34:331-332.

1969h Presentation of "A guide to the identification of Florida projectile points." Eastern States Archeological Federation, Bulletin 27-28:21.

1969i (with M.H. Wing). A scraper with graver spurs from Florida. Florida Anthropologist 21:94-95.

1969j A silver ornament from St. Cloud, Florida. Florida Anthropologist 21:36-38.

1969k Southern limit of Timucua territory. Florida Historical Quarterly 47:414-419.

1969l Unfinished Bolen points from Hillsborough County. Florida Anthropologist 21:34-35.

1970a The archaeology of Grenada, West Indies, and the spread of ceramic people in the Antilles. Proceedings of the Third International Congress for the Study of Pre-Columbian Cultures in the Lesser Antilles, Grenada, 1969, pp. 147-152.

1970b (with Mario Mattioni). A chronological chart for the Lesser Antilles: sites dated by ceramic typology. Proceedings of the Third International Congress for the Study of Pre-Columbian Cultures in the Lesser Antilles, Grenada, 1969, pp. 1-3.

1970c A Clovis fluted point from the Santa Fe River, Florida. Florida Anthropologist 22:36-37.

1970d Comments on Garry W. Stone's paper: "Ceramics in Suffolk County, Mass., inventories, 1680-1775." The Conference on Historic Site Archaeology, Papers 1968 3[2]:127-129.

1970 (with A. K. Bullen). The Lavoutte site,St. Lucia: a Carib ceremonial center. Proceedings of the Third International Congress for the Study of Pre-Columbian Cultures of the Lesser Antilles, Grenada, 1969, pp. 48-86.

1970 f Pottery, radiocarbon dates, and sea level rises. Proceedings of the VIII International Congress of Anthropological and Ethnological Sciences, Tokyo and Kyoto, 1968, 3:168-169.

$1970 \mathrm{~g}$ Preface to Sur le chemin des anciens potiers, by Mario Mattioni. Editions Maritimes et d'Outre-Mer, Paris.

1970h Regionalism in Florida during the Christian era. Florida Anthropologist 23:57-61.

1970i (with W.L. Partridge and D.A. Harris). The Safford burial mound, Tarpon Springs, Florida. Florida Anthropologist 23:81-118.

$1970 \mathrm{j}$ (with H.B. Greene). Stratigraphic tests at Stalling's Island. Georgia. Florida Anthropologist 23:8-28.

1970k (with $\mathrm{H}$. Theuvenin and M. Sanoja O.). Terminologie utilisée pour la description des poteries des Petites Antilles, equivalence des termes Anglais, Espagnols et Français. Proceedings of the Third International Congress for the Study of Pre-Columbian Cultures of the Lesser Antilles, Grenada, 1969, pp. 4-7.

1970 (with S.D. Webb and B.I. Waller). A worked mammoth bone from Florida. American Antiquity 35:203-205

1971a Archaeology: Caribbean area. Handbook of Latin American Studies 33:61-66. University of Florida Press, Gainesville.

$1971 \mathrm{~b}$ The beginnings of pottery in eastern United States as seen from Florida. Eastern States Archeological Federation, Bulletin 30:10-11.

1971c Comments on Greer's paper on alkaline glaze. The Conference on Historic Site Archaeology, Papers 1970 5:186-187.

1971d (with H.G. Smith). Fort San Carlos. Notes in Anthropology 14. Department of Anthropology, Florida State University, Tallahassee.

1971e The Safety Harbor period: a brief statement. Southeastern Archaeological Conference [1961], Newsletter 10(2):50-51.

1971 f The Sarasota County Mound, Englewood, Florida. Florida Anthropologist 24:1-30.

$1971 \mathrm{~g}$ Some variations in settlement patterns in peninsular Florida. Southeastern Archaeological Conference [1970], Bulletin 13:10-19. 
1971h The transitional period of southern southeastern United States as viewed from Florida, or the roots of the Gulf tradition. Southeastern Archaeological Conference [1970], Bulletin 13:63-70.

1972a (with A.K. Bullen). Archaeological investigations on St. Vincent and the Grenadines, West Indies. The William C. Bryant Foundation, American Studies, Report 8.

$1972 \mathrm{~b}$ Culture change, growth, and borrowing as evidenced by Florida archaeology-a study in regionalism. VII Congrès International des Sciences Anthropologiques et Ethnologiques, Moscou [Moscow], 1964, 11:4751.

1972c (with M.T. Wallace). An engraving tool from north Florida. Florida Anthropologist 25:131-132.

1972 dedited with J.B. Stoltman). Fiber-tempered pottery in southeastern United States and northern Columbia: its origins, context, and significance. Florida Anthropological Society, Publications 6.

1972e (with L.E. Beilman). The Nalcrest site, Lake Weohyakapka, Florida. Eastern States Archeological Federation, Bulletin 31:9-10.

$1972 \mathrm{f}$ The Orange period of peninsular Florida. In Fiber-tempered pottery in southeastern United States and northern Columbia: its origins, context, and significance. Florida Anthropological Society, Publications 6:9-33.

$1972 \mathrm{~g}$ (with M. Mattioni). Some ceramic variations at Vivé, Martinique. Atti del XL Congresso Internazionale degli Americanisti, Roma-Genova, 1972, 1:225-229.

1972h A stone bird head plummet from Kissimmee, Florida. Florida Anthropologist 25:92.

1973a Archaeology: Caribbean area. Handbook of Latin American Studies 35:46-49. University of Florida Press, Gainesville.

1973b (with A.K. Bullen and I.A.E. Kirby). Dating the Troumasée decorated cylinder: a horizon style. Proceedings of the Fourth International Congress for the Study of Pre-Columbian Cultures of the Lesser Antilles, St. Lucia, 1971, pp. 197-198.

1973c Further comments on Antillean petroglyphs. Proceedings of the Fourth International Congress for the Study of Pre-Columbian Cultures of the Lesser Antilles. St. Lucia, 1971, pp. 65-67.

1973d (with A.K. Bullen and E.M. Branford). The Giraudy site, Beane Field, St. Lucia. Proceedings of the Fourth International Congress for the Study of Pre-Columbian Cultures of the Lesser Antilles, St. Lucia, 1971 , pp. 199-214.

1973e Introduction [new] to Gordon R. Willey's Archeology of the Florida Gulf Coast. Reprint edition for Peabody Museum of Archaeology and Ethnology, Harvard University, pp. 7-11. AMS Press, New York.

1973f Krum Bay, a preceramic workshop on St. Thomas. Proceedings of the Fourth International Congress for the Study of Pre-Columbian Cultures of the Lesser Antilles, St. Lucia, 1971, pp. 110-114.

1973g (with L.E. Beilman). The Nalcrest site, Lake Weohyakapka, Florida. Florida Anthropologist 26:1-22.

1973h Petroglyphs of the Virgin Islands and Puerto Rico. Proceedings of the Fourth International Congress for the Study of Pre-Columbian Cultures of the Lesser Antilles, St. Lucia, 1971, pp.13-16.

1973i Re: Petroglyphs in Guyana. Proceedings of the Fourth International Congress for the Study of PreColumbian Cultures of the Lesser Antilles, St. Lucia, 1971, p. 65.

1973j (with A.K. Bullen). Settlement pattern and environment in pre-Columbian eastern Dominican Republic. Boletín del Museo del Hombre Dominicano 3:315-324.

1973k Stone specimens from St. Barthélemy. Proceedings of the Fourth International Congress for the Study of Pre-Columbian Cultures of the Lesser Antilles, St. Lucia, 1971, pp. 82-83.

1973l Stratigraphic tests at two sites on Guadeloupe. Proceedings of the Fourth International Congress for the Study of Pre-Columbian Cultures of the Lesser Antilles, St. Lucia, 1971, pp. 192-196.

1974a Certain petroglyphs of the Antilles. Proceedings of the Fifth International Congress for the Study of Pre-Columbian Cultures of the Lesser Antilles, Antigua, 1973, pp. 94-109.

1974b (with A.K. Bullen). Further notes on the West Bay site. Florida Anthropologist 27:119.

1974c (with A.K. Bullen). Inferences from cultural diffusion to Tower Hill, Jamaica, and Cupercoy [Cupecoy] Bay, St. Martin. Proceedings of the Fifth International Congress for the Study of Pre-Columbian Cultures of the Lesser Antilles, Antigua, 1973, pp. 48-60.

$1974 \mathrm{~d}$ The origins of the Gulf Tradition as seen from Florida. Florida Anthropologist 27:77-88.

1974e (with P.M. Lien and C.H. Webb). A Poverty Point owl amulet found in Florida. Florida Anthropologist 27:165-168.

$1974 \mathrm{f}$ (with M. Mattioni). Pre-Columbian dogs in the Lesser and Greater Antilles. Proceedings of the Fifth International Congress for the Study of Pre-Columbian Cultures of the Lesser Antilles, Antigua, 1973, pp. 162-165.

$1974 \mathrm{~g}$ (with O. Jahn and M.J. Brooks). Some tests at the Zellwood site (Or-17) beside Lake Apopka, Florida. Florida Anthropologist 27:62-66.

1974h (with A.K. Bullen). Stone mortars in Florida. Florida Anthropologist 27:169-170.

1974 (with A.K. Bullen). Tests at Hacienda Grande, Puerto Rico. Fundación Arqueológica, Antropológica e Histórica de Puerto Rico, Boletín Informativo (Edición Especial) 1:1-6 (plus 5 plates).

1974j Were there pre-Columbian cultural contacts between Florida and the West Indies: the archaeological evidence. Florida Anthropologist 27:149-160.

1975a Archaeology: Caribbean area. Handbook of Latin American Studies 37:48-52. University of Florida Press, Gainesville. 
1975b A guide to the identification of Florida projectile points (revised edition). Kendall Books, Gainesville. (62 pp.)

1975c Implications from some Florida deposits and their archaeological contents. Florida Anthropologist 28: 73-84.

1975d Suwannee-like points from southwestern Georgia. Florida Anthropologist 28:52.

1976a (with A.K. Bullen). Culture areas and climaxes in Antillean prehistory. Proceedings of the Sixth International Congress for the Study of Pre-Columbian Cultures of the Lesser Antilles, Guadeloupe, 1975, pp. 1-10.

1976b Culture changes, radiocarbon dates, and trade in the Antilles. Actas del XLI Congreso Internacional de Americanistas, México, 1974, 3:600-607.

1976c Did Paleolithic, Archaic, or Formative man enter the Antilles from Florida? Actas del XLI Congreso Internacional de Americanistas, México, 1974, 3:592-599.

1976d (with A.K. Bullen). The Palmer site. Florida Anthropological Society, Publications 8. (55 pp. plus 23 plates)

1976e The preceramic periods of Florida and the Lesser Antilles. Proceedings of the First Puerto Rican Symposium on Archaeology [1973], San Juan. Fundación Arqueológica, Antropológica e Histórica de Puerto Rico, Report 1:9-24.

1976 f Some thoughts on Florida projectile points. Florida Anthropologist 29:33-38.

$1976 \mathrm{~g}$ (with A.K. Bullen). Three stratigraphic tests along the eastern shore of Trinidad. Proceedings of the Sixth International Congress for the Study of Pre-Columbian Cultures of the Lesser Antilles, Guadeloupe, 1975, pp. $28-34$.

1978a (with W. Askew, L.M. Feder, and R.L. McDonnell). The Canton Street site, St. Petersburg, Florida. Florida Anthropological Society, Publications 9.

1978b Pre-Columbian trade in eastern United States as viewed from Florida. Florida Anthropologist $31: 92-108$.

1978c (with O. Jahn). The Tick Island site, St. Johns River, Florida. Florida Anthropological Society, Publications 10. (In press, ms. 1976).

1978d Tocobaga Indians and the Safety Harbor culture. In Tacachale: essays on the Indians of Florida and southeastern Georgia during the historic period [1973], edited by J.T. Milanich and S. Proctor. Ripley P. Bullen Monographs in Anthropology and History, No. 1, pp. 50-58. University Presses of Florida, Gainesville.

n.d. (posthumously with Rochelle Marrinan). Fiber-tempered pottery. In The Southeast, vol. 14, Handbook of North American Indians, chapter 46, edited by R.D. Fogelson (volume editor) and W.C. Sturtevant (general editor). Smithsonian Institution, Washington, D.C. (In press, Bullen ms. 1972.) 